\title{
Woody Vegetation Persistence and Disturbance in Central Texas Grasslands Inferred From Multidecadal Historical Aerial Photographs
}

\author{
Darrel B. Murray, ${ }^{1}$ Joseph D. White, ${ }^{2,4}$ and Pamela Swint ${ }^{3}$ \\ Authors are ${ }^{1} \mathrm{PhD}$ Candidate, ${ }^{2}$ Professor, and ${ }^{3} \mathrm{MS}$ Graduate, Department of Biology, Baylor University, Waco, TX 76798, USA; and ${ }^{4}$ Director, The \\ Institute of Ecological, Earth, and Environmental Science, Baylor University, Waco, TX 76798, USA.
}

\begin{abstract}
Woody vegetation encroachment has been assumed to occur uniformly over the past century across the southern Great Plains of the United States. To assess this assumption, we evaluated changes in pixels classified as woody vegetation from aerial photographs from 1937 to 2004 that were acquired approximately every 13 yr for a 7109-ha wildlife refuge located in the eastern Edwards Plateau region of central Texas. We found that the percentage of total area classified as woody vegetation changed minimally (62.0-64.2\%) from 1937 to 2004. However, on average, 32\% of the study area changed classification between woody vegetation and nonwoody vegetation pixels between each photograph date. To assess potential causes of woody vegetation change, we analyzed contiguous pixels with area $\leq 1$ ha and area $>1$ ha representing small- and large-scale disturbances, respectively. Small-scale woody vegetation pixel loss was found to be moderately low, ranging between $11.1 \%$ and $12.6 \%$ of the study area for the period of analysis, indicating relatively constant levels of canopy-level disturbance. Large-scale woody vegetation pixel loss peaked in the 1951-1964 time interval, where we identified 98 patches averaging 8.1 ha and covering $7.6 \%$ of the study area. The timing and area of these potential disturbances were correlated with drought and increased fire frequency within our study area. This methodology, which includes careful georectification and radiometric standardization of the historical photographs, can be used to detect interdecadal variability related to changes in types of disturbance over longer periods of time. This study also shows that repeated observations, such as those from aerial photographs, may be required to adequately characterize woody plant encroachment, particularly in subhumid grasslands, where disturbance and regrowth of woody plants may occur at decade time scales.
\end{abstract}

Key Words: aerial photos, drought, fire, patch mosaic, woody vegetation encroachment

\section{INTRODUCTION}

Woody vegetation encroachment within the southern Great Plains of the United States during the past century has been associated with climate change and land use, including increased grazing by livestock concomitant with loss of fine fuels and reduced frequency of wildfires (Rippel et al. 1983; Ansley et al. 1995; Van Auken 2000). However, woody plant encroachment is often not a homogeneous process, depending on the intensity and frequency of disturbance factors within a region. Interpretation of broad-spatial-scale, long-term trends in woody vegetation coverage may be site specific and influenced by observation frequency.

Grasslands with site water balances of $<400 \mathrm{~mm}$ per year have the potential for encroachment with productivity typically subject to combined climate variability and disturbance (Woodward 1987). In regions where long-term adequate precipitation occurs, canopy closure may occur in woody vegetation patches with reduced disturbance (Scholes and Archer 1997; Sankaran et al. 2005). As a function of varying precipitation inputs, topography, soil water-holding capacity,

\footnotetext{
Research was funded by the US Geological Society-US Fish and Wildlife Service Science Support Program and the Glasscock Foundation and Smith Fellowship of Baylor University.

Correspondence: Darrel B. Murray, Dept of Biology, Baylor University, P0 Box 97388, Waco, TX 76798, USA. Email: Darrel_Murray@Baylor.edu
}

Manuscript received 23 September 2011; manuscript accepted 28 November 2012.

(c) 2013 The Society for Range Management and vegetation-specific transpiration rates, woody cover can reach a site maximum and then show short-term fluctuation rather than directional change due to climatic variability and disturbance (Browning et al. 2008). In areas that have reached a potential climatic site maximum of woody vegetation cover, frequent disturbances, such as severe drought and intense wildfire, decrease woody vegetation cover, while less frequent, less intense disturbances, such as low-intensity fire, may increase the likelihood of woody vegetation persistence by reducing understory competition (Yao et al. 2012).

To characterize woody vegetation change, it is important to consider history of land use and disturbance of an area along with the frequency and reference point of observation (Swetnam et al. 1999; Lawes et al. 2004). It is widely accepted that broad-scale, long-term encroachment of woody vegetation within grasslands is coincident with land use changes since European settlement, especially those that resulted in reduced fire (Foster 1917; Wink and Wright 1973; Van Auken 2000). However, within this long-term trend, variability exists resulting from disturbances of different scales and intensity. Observed change in woody vegetation cover within shrub and woodland ecoregions is often related to regrowth following periodic disturbance, including clearing to increase herbaceous production for grazing (Drummond et al. 2012), drought (Allen and Breashears 1998), and fire (Archer et al. 1988).

Across the United States, studies indicate that increased juniper densities in historical grasslands, including increases in western juniper (Juniperus occidentalis Hook; Miller and Rose 1999), eastern redcedar (Juniperus virginiana L.; Briggs et al. 
2002; Engle et al. 2008), and redberry juniper (Juniperus pinchotti Sudw.; Uekert et al. 2001), are often related to land use changes. However, the rates and types of land use changes affecting woody vegetation encroachment have varied greatly. Changes in regional land uses in the Great Plains are tied to climate, soil fertility, and socioeconomic factors (Coppedge et al. 2002; Drummond et al. 2012), making broad-scale generalizations concerning juniper encroachment difficult.

The rates and processes of juniper regrowth after disturbance differ from establishment and are species specific (Van Auken et al. 2004), which also adds to the complexity of discerning growth trends. For example, following mechanical control of redberry juniper within the northwest Edwards Plateau region, recovery growth was rapid at $1 \%$ woody vegetation cover per year, resulting from resprouting, release of juveniles, and establishment from existing seed banks (Ueckert et al. 2001). The increase of eastern redcedar from east to west across the Great Plains, although a large-scale process, has been heterogeneous as a consequence of fire exclusion and intentional plantings, followed by efforts at eradication and regrowth (Engle et al. 2008). For the Edwards Plateau in Texas, Ashe's juniper (Juniperus ashei J. Buchholz) has been described as expanding into grasslands due to similar factors described in other studies, coupled with its high growth and reproductive rates (Fuhlendorf and Smeins 1997; Van Auken 2008).

In this study, we detected changes in Ashe's juniperdominated woody vegetation at near-decadal time scales over a 66-yr period utilizing historical aerial photographs acquired in 1937, 1951, 1964, 1980, 1995, and 2004. Because of the relatively short intervening time periods between photograph acquisition, we assessed the potential causes of woody vegetation disturbance and establishment based on woody patch appearance and disappearance over time (Kettle et al. 2000; Bowman et al. 2001; Fensham et al. 2003; Narumalani et al. 2004). From this analysis, we expected to detect that woody plants have not increased cover in this region since 1937 but rather have reorganized in the landscape through patch dynamics influenced by interactions between climate, topography, land use, and fire. By covering a large area over a long time extent, coupled with frequent photography, we hoped to document changes in long-lived woody vegetation where in situ data are absent. This study is intended to improve interpretation of woody plant encroachment for the past century and provide information for disturbance management in southern Great Plains grasslands of the United States.

\section{METHODS}

\section{Site Description}

To assess woody vegetation changes over time, we chose the Balcones Canyonlands National Wildlife Refuge (BCNWR), a 7109-ha refuge located on the eastern edge of the Edwards Plateau northwest of Austin, Texas, USA (Fig. 1). This refuge is composed of noncontiguous tracts of land that range in size from 38 to 1655 ha, most of which were previously used for cattle and goat ranching. The refuge was established in 1992 to conserve habitat for the endangered golden-cheeked warbler (Dendroica chrysoparia Sclater and Salvin) and the black-

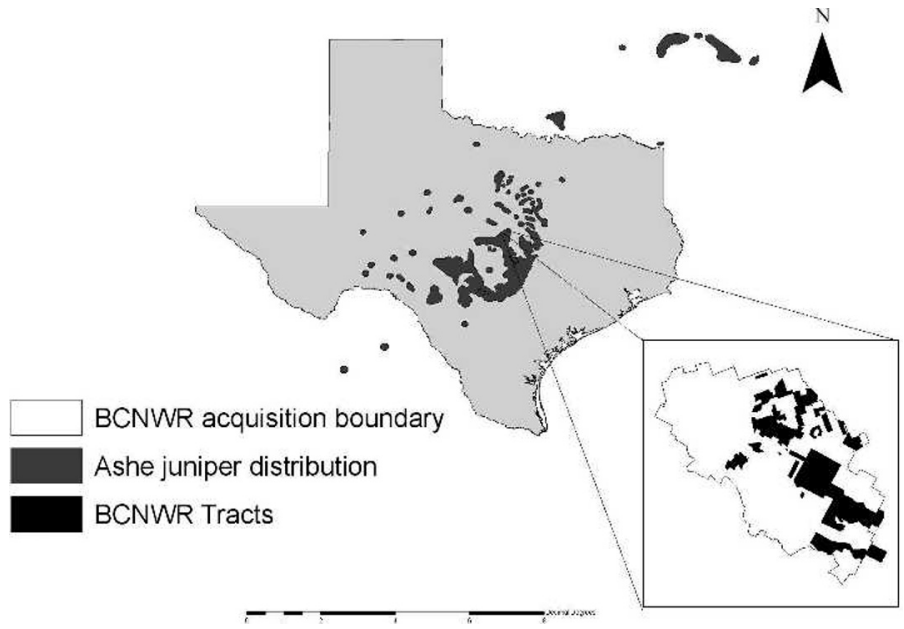

Figure 1. Distribution of Ashe's juniper woodlands (US Geological Survey 1999) and the BCNWR in central Texas.

capped vireo (Vireo atricapilla Woodhouse; US Fish and Wildlife Service 1992). These species require habitat composed of closed mature juniper and oak woodlands and more open areas with short shin oak, respectively. Habitat management for these species has included combinations of juniper removal and prescribed burning since 1995 .

The BCNWR is located within the Southwest Plateau and Plains Dry Steppe and Shrub Province of the United States and is dominated by grasslands composed of native little bluestem (Schizachyrium scoparium [Michx.] Nash) and the exotic King Ranch bluestem (Bothriochloa ischaemum [L.] Keng). Woody patches located within the grassland are dominated by Ashe's juniper with co-occurring hardwood species, such as Texas red oak (Quercus buckleyi Nixon \& Dorr), plateau live oak (Quecus fusiformis Small), scalybark oak (Quercus sinuata Walter), escarpment black cherry (Prunus serotina Ehrend.), and post oak (Quercus stellata Wangenh.). The topography of the area consists of hills, valleys, and steep canyons with highly sloped drainages of eroded limestone primarily from the Glen Rose formation of Cretaceous origin (Sellards et al. 1933). Mean annual precipitation is $855 \mathrm{~mm}$, and mean annual minimum and maximum temperatures range from $5.7^{\circ} \mathrm{C}$ to $16.8^{\circ} \mathrm{C}$ in winter and $22.4^{\circ} \mathrm{C}$ to $33.5^{\circ} \mathrm{C}$ in summer (National Oceanic and Atmospheric Administration 2009) with the area climatically classified as subhumid and subtropical.

\section{Aerial Photograph Preparation and Standardization}

We acquired panchromatic aerial photographs and false-color infrared Digital Orthophoto Quadrangles (DOQ) ranging in spatial resolution from 1:15840 to 1:20000 from the Texas Natural Resource Information Service (TNRIS), US Geological Survey, and Tobin International, Ltd, a private firm. Aerial panchromatic photographs from 1937, 1951, 1964, and 1980 were digitized on a flat-bed scanner at 500 dots per inch with an eight-bit radiometric resolution. To compare the panchromatic aerial photographs to the false-color infrared DOQ data, we averaged the green, red, and near infrared channel digital number values of the DOQ data to simulate the panchromatic reflection of the photos. We georeferenced all digitized photos (Imagine 9.3; ERDAS, Norcross, GA) to the 1995 and 2004 
Table 1. Acquisition date, photo scale, pixel spatial resolution, number of photos acquired, and mean $r^{2}$ value of linear regression equations used to standardize digital number values with the $2004 \mathrm{DOQ}$ data for each photograph year. ${ }^{1}$

\begin{tabular}{|c|c|c|c|c|c|}
\hline Photograph year & Acquisition date & Photo scale & Pixel spatial resolution (m) & No. of photos & Average $r^{2}$ \\
\hline 1937 & November 1937 & $1: 18000$ & 0.9 & 4 & $0.63( \pm 0.13)$ \\
\hline 1951 & January 1951 & $1: 15840$ & 0.8 & 25 & $0.49( \pm 0.19)$ \\
\hline 1964 & October 1964-January 1966 & $1: 20000$ & 1.0 & 35 & $0.51( \pm 0.19)$ \\
\hline 1980 & November 1980-May 1981 & $1: 15840-1: 20000$ & $0.8-1.0$ & 52 & $0.61( \pm 0.21)$ \\
\hline 1995 & January 1995 & $1: 12000$ & 1.0 & 10 & $0.63( \pm 0.16)$ \\
\hline 2004 & December 2004 & $1: 12000$ & 1.0 & 10 & NA \\
\hline
\end{tabular}

${ }^{1} \mathrm{NA}=$ not applicable.

DOQ data by identifying features, such as rocky outcrops, roads, and houses, as ground control points. Because the photographs were collected at different flight heights, spatial resolution of the photographs varied from $0.8 \mathrm{~m}$ to $1.0 \mathrm{~m}$ (Table 1 ). We resampled all images to a $1 \times 1 \mathrm{~m}$ pixel size to standardize images for our analysis.

To standardize the radiometric range of photographs acquired for the same year, we located 25 points in overlap areas between photograph pairs and constructed linear regression models from their respective digital number values. We normalized all images for each photographed year by inverting the derived regression models to calculate adjusted digital numbers. Because this regression modeling only affected the mean values of the comparison images, we used histogram matching (Imagine 9.3) to scale variances between images. Histogram matching of each image was accomplished by comparing the frequency distribution of digital number values that were matched to the means and standard deviation of a reference image. Analysis of resultant ranges of digital number values showed similar distribution for each image within each photographed year.

To standardize the radiometric range of photographs acquired for different years, we randomly selected 25 points to extract digital number values for images from each photographed year. We compared these data with digital numbers from the 2004 images to construct a linear regression model for each photographed year (Table 1). We then derived inverted regression models for each time period and calculated adjusted digital numbers.

To classify pixels, we established a threshold value of 115 by trial and error where pixels with digital number values $\leq 115$ were assigned as woody vegetation and $>115$ were assigned as nonwoody vegetation. Accuracy was determined from 105 randomly chosen locations where vegetation type was determined from the line-intercept method for two 30-m transects oriented perpendicular to each other. This method categorized vegetation into the two classes with a 94\% accuracy level. Careful georectification and standardization of the images provided consistent delineation of woody vegetation and nonwoody pixels across the photographed years. This provided confidence that pixel changes apparent in the images accurately reflected changes in woody vegetation through time.

\section{Aerial Photograph Change Analysis}

To assess the amount of change between photographed time intervals, we compared the classification of each pixel for the following time intervals: 1937-1951, 1951-1964, 1964-1980,
1980-1995, and 1995-2004. We categorized each pixel as no change, woody vegetation loss, or woody vegetation gain, depending on the result of this change analysis. To estimate overall loss or gain of woody vegetation pixels between photographed years, we tabulated the number of woody vegetation pixels that changed.

From the change analysis, we also identified potentially disturbed areas in the data by classifying pixels as either woody vegetation loss or other. Next, the adjacent eight pixels bordering each pixel classified as woody vegetation loss were analyzed to determine the size of woody vegetation loss area. We referred to groups of pixels classified as woody vegetation loss as a patch. Patches with area $\leq 1$ ha were referred to as small scale, and patches with area $>1$ ha were referred to as large scale. We interpreted small-scale patches as small-scale, diffuse disturbance events potentially associated with canopy gap formation, such as windthrow and ice damage. Large-scale patches were interpreted as large-scale, contiguous disturbances potentially associated with common historical large-scale events, such as fire and tree harvesting. Areas of recent prescription cutting or burning performed by the USFWS resulted in areas of contiguous woody vegetation loss and were used in the accuracy assessment described below. For largescale patches, we calculated average patch size, percent area, and number of patches to assess changes in landscape composition over time (FRAGSTATS; McGarigal et al. 2002).

To verify patch classification, we identified sites within the study area as having known tree removal or burning prescriptions during the 1995-2004 time interval. Boundaries of 16 prescription areas ranging in size from 8.1 ha to 234 ha (C. Schwope, personal communication, May 2008) were overlaid digitally with the large-scale woody vegetation pixel loss patch images to visually assess if these areas could be detected with this methodology. Detection of known areas of tree removal or burning in the 1995-2004 photograph interval would give further validation that large-scale woody vegetation pixel loss patches detected in earlier photograph intervals are potentially related to historical disturbances such as tree harvesting and fire.

To characterize topographic factors influencing large-scale woody vegetation pixel loss, we identified 262 patches from all time intervals and analyzed topographic location and configuration. We derived median topographic slope and aspect values for each large-scale woody vegetation pixel loss patch from a 30-m resolution digital elevation model (DEM) acquired from TNRIS. Slopes were grouped into flat slopes $\left(\leq 5^{\circ}\right)$ and steep slopes $\left(\geq 10^{\circ}\right)$ based on personal observation of terrain 
for the study area. Aspects were grouped into cardinal directions represented as north $\left(\geq 315^{\circ}\right.$ to $\left.<45^{\circ}\right)$, east $\left(\geq 45^{\circ}\right.$ to $\left.<135^{\circ}\right)$, south $\left(\geq 135^{\circ}\right.$ to $\left.<225^{\circ}\right)$, and west $\left(\geq 225^{\circ}\right.$ to $<315^{\circ}$ ). To determine the expected proportions of the topographic slope and aspect values for the landscape, we constructed a uniform grid of points $30 \mathrm{~m}$ apart covering a DEM of the study area. We performed a one-sample chi-square test to assess differences between proportions of observed large-scale patches located on flat and steep sites as compared to expected proportions derived from the entire study area. For steep-slope large-scale patches, we performed a one-sample chisquare test to test if observed frequencies significantly differed by aspect from expected frequencies. We assumed that aspect would be more influential on disturbance for steep areas. Utilizing the DEM to visually assess surrounding topography, we tested for significant differences for observed versus expected proportions (assumed as 50:50) of flat large-scale patches found on hilltops versus those found within valleys with a one-sample chi-square test.

\section{RESULTS}

The percentage of pixels classified as woody vegetation in 1937 was $62.0 \%$ and increased to $64.2 \%$ by 2004 , for a total net increase of 156 ha (Fig. 2). Of the pixels classified as woody vegetation present in 1937 (4407.2 ha), 29.1\% remained classified as woody vegetation for all photograph years. The largest change in woody vegetation pixels $(4.4 \%)$ occurred across three photographed time intervals between 1964 and 2004. The percentage of pixels that changed from nonwoody to woody vegetation and vice versa decreased from $37 \%$ in the 1937-1951 time interval to $24 \%$ in the $1995-2004$ time interval (Fig. 3). The percentage of pixels that did not change classification between successive time intervals increased from $63 \%$ to $76 \%$ from 1937 to 2004 .

The percentage of pixels categorized as small-scale versus large-scale woody vegetation pixel loss patches showed different trends for the analysis period (Fig. 4). The percentage of small-scale woody vegetation pixel loss remained fairly constant across all years with values of $11.1-12.6 \%$. The percentage of large-scale woody vegetation pixel loss was highest during the 1951-1964 time interval, with a value of $7.6 \%$ of the total refuge area affected, then decreased to a value of $0.7 \%$ during the $1995-2004$ interval. Within the known tree removal and burn prescription areas, 13 of 16 (81\%) observed woody vegetation loss patches were correctly identified as large-scale woody vegetation pixel loss patches.

The highest average large-scale woody vegetation loss patch size we found (8.1 ha) was during the 1951-1964 period, which also had the highest number of patches (98) and highest proportion of the BCNWR (7.6\%; Fig. 5). After 1964, average patch size, percent area, and number of large-scale patches generally declined, with the exception of an increased average patch size of 5.8 ha occurring in the 1995-2004 time interval.

Our analysis of topographic position of large-scale woody vegetation pixel loss patches showed that $63 \%$ occurred on flat positions and $37 \%$ on steep positions (Fig. 6), which was significantly different than the expected $80 \%$ flat and $20 \%$ steep $\left(\chi^{2}=36.1, P=.05\right)$. Large-scale woody vegetation loss

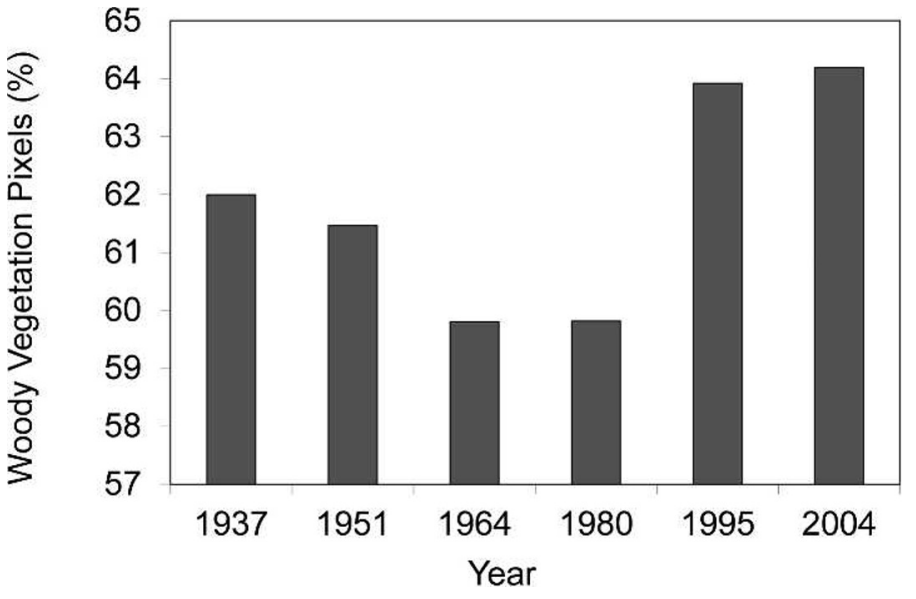

Figure 2. Pixels classified as woody vegetation pixels expressed as a percentage (\%) for the BCNWR from aerial photographs taken in 1937, 1951, 1964, 1980, 1995, and 2004.

patches located on steep slopes occurred more frequently on south-facing $(36 \%)$ and west-facing $(38 \%)$ aspects $\left(\chi^{2}=21.7\right.$, $P=.05)$ than the expected $29 \%$ south-facing and $20 \%$ westfacing aspects derived for the entire study area. For flat terrain, significantly more large-scale patches occurred on hilltops $(66 \%)$ than within valleys $\left(34 \% ; \chi^{2}=68.4, P=.05\right)$.

\section{DISCUSSION}

Our results showed that total area classified as woody vegetation pixels remained fairly constant for the period of analysis (Fig. 2). Woody vegetation has encroached in grasslands of this ecological province beyond its historical norm in recent decades (Rippel et al. 1983; Ansley et al. 1995; Engle et al. 2008). However, our results indicate that current woody vegetation cover of the eastern boundary of the Edwards Plateau may have simply recovered to 1937 levels. The eastern Edwards Plateau may have higher sustained woody vegetation cover associated with combined proximity to the Gulf Coast and its maritime climatic influence and topoedpahic features (Diamond and True 2008). Therefore, further expansion of woody vegetation is not necessarily expected given that woody vegetation may have reached a climatic site maximum sometime before 1937. Browning et al. (2008) found that Sonoran arid grasslands reached a climatic site maximum woody cover of $35 \%$, depending on soil type, and then fluctuated with no detectable directional change based on aerial photo analysis.

Once at a climatic site maximum, these woodland-grassland systems may behave as shifting mosaics as proposed by Bormann and Likens (1979), where the proportion of patches in the landscape at different developmental stages remains constant, with single patches gaining and losing biomass, while total biomass of the system remains fairly constant in the absence of a large-scale exogenous disturbance. For our study area, variable site water availability due to soils and topography, coupled with periodic droughts, disturbance, and stand-level density-dependent thinning, may create transient 


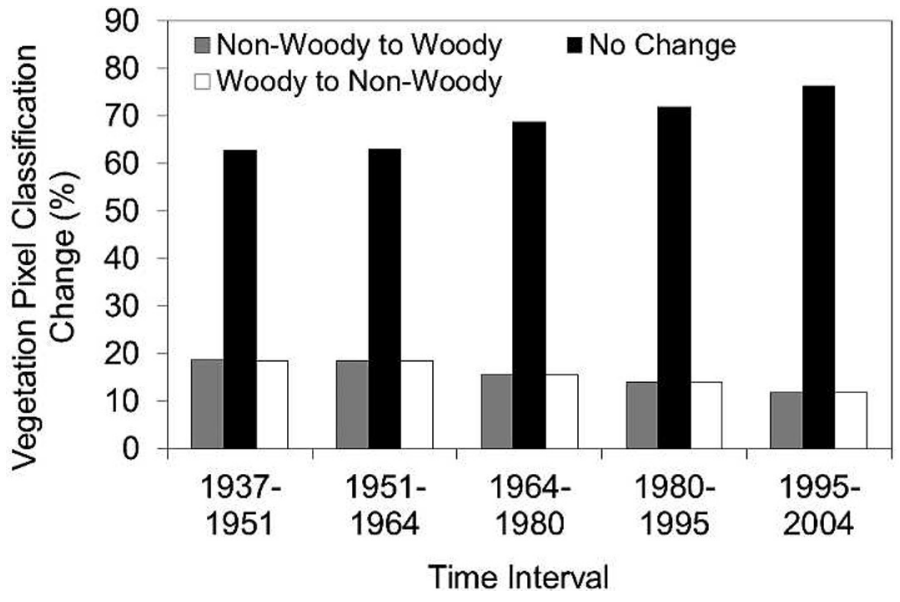

Figure 3. Percentage of pixels which changed classification for BCNWR for the time intervals 1937-1951, 1951-1964, 1964-1980, 1980-1995, and 1995-2004.

patches of woody vegetation similar to the shifting mosaic paradigm envisioned by Bormann and Likens.

Extreme droughts during the 1930s and 1950s are likely to have contributed to woody vegetation loss directly or through interactions with other disturbance, resulting in decreased woody vegetation, as observed throughout the south-central and southwestern United States during these time periods (Archer et al. 1988; Allen and Breshears 1998; Swetnam and Betancourt 1998; Mueller et al. 2005). Changes in woody cover are associated with persistent changes in precipitation lasting more than 1-2 yr (Archer et al. 1988; Allen and Breashears 1998; Banfai and Bowman 2006). These results coincide with the timing of highest large-scale woody vegetation pixel loss area and number of patches (Fig. 5). From 1964 to 1995, decreased disturbance coincident with increased absentee ownership and moister climate may have resulted in increased contiguity and area of patches of woody vegetation. Sankaran et al. (2005) found that semiarid savannas in Africa with mean annual precipitation above $650 \mathrm{~mm}$ were unstable systems,

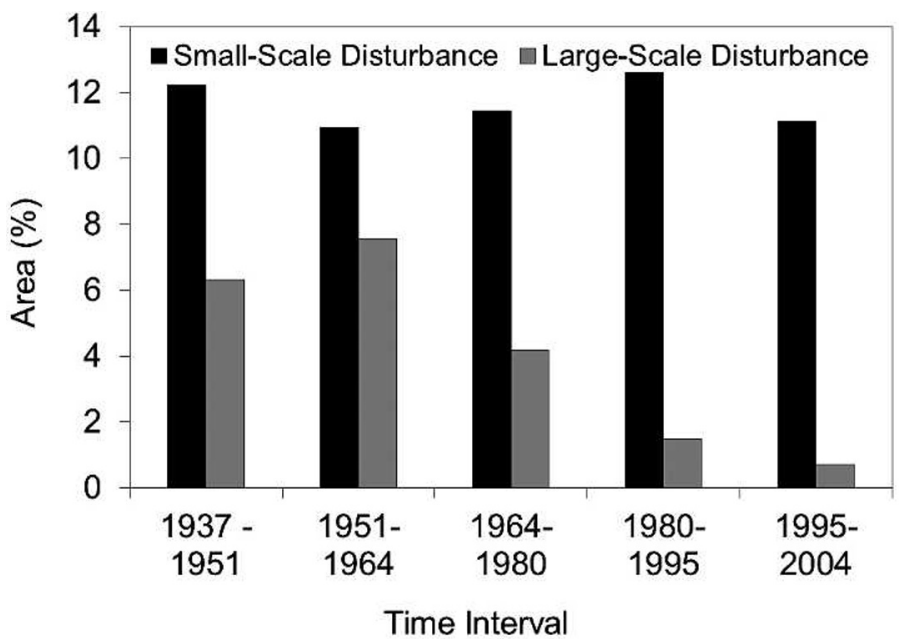

Figure 4. Percentage of BCNWR area characterized as small or large-scale woody vegetation pixel loss patches for the time intervals 1937-1951, 1951-1964, 1964-1980, 1980-1995, and 1995-2004.

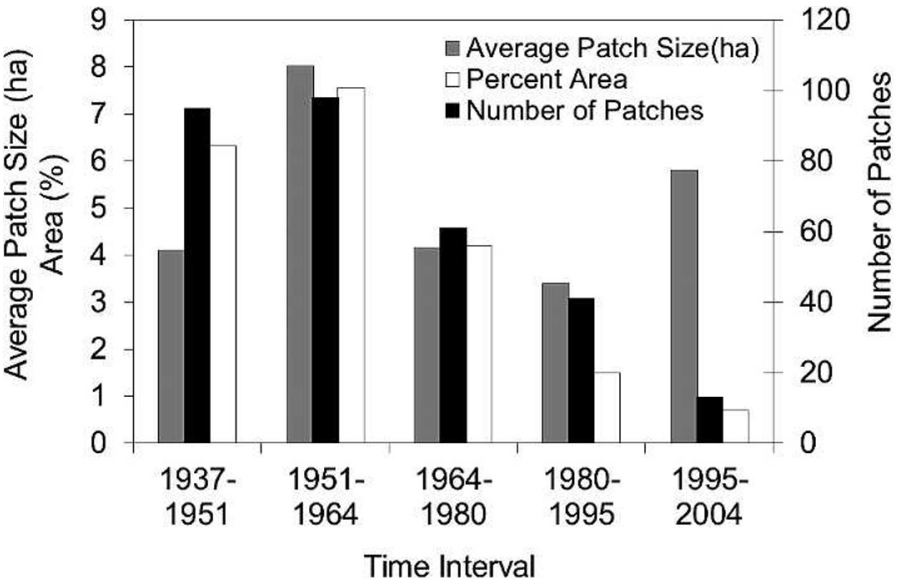

Figure 5. Average size in hectares, percent area, and number of patches of large-scale woody vegetation pixel loss for BCNWR for the time intervals 1937-1951, 1951-1964, 1964-1980, 1980-1995, and 1995-2004.

where precipitation was enough to allow canopy closure and disturbance was required for tree-grass coexistence. We attribute the increase in large-scale woody vegetation pixel loss patches between 1995 and 2004 to management activities within the refuge, including documented tree removal and prescribed burning (C. Schwope, personal communication, May 2008) that we used to assess the accuracy $(81 \%)$ of our large-scale disturbance detection methodology.

The eastern Edwards Plateau may retain woody vegetation on its steep slopes in the absence of repeated clearing due to

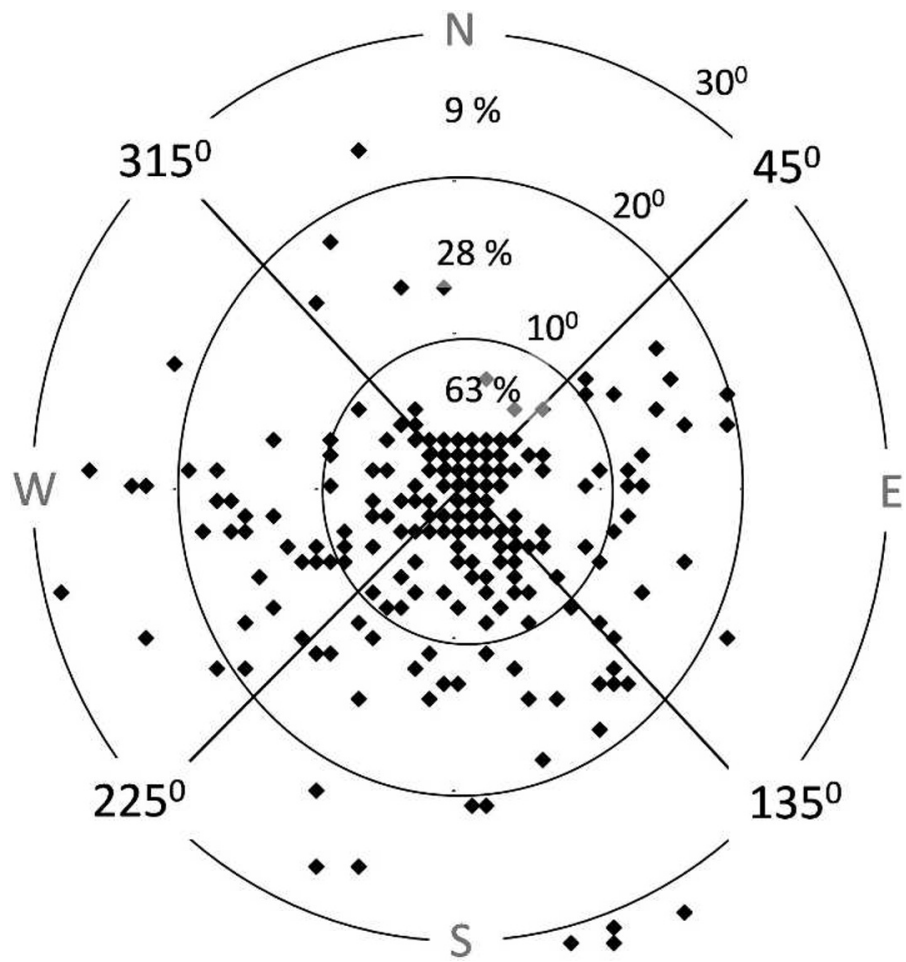

Figure 6. Radial plot of topographic slope (degrees) and aspect (north, south, east, west) of large-scale woody vegetation pixel loss patches for BCNWR analyzed for this study. The percentage of contiguous woody vegetation pixel loss patches within each slope category is shown. 
establishment failures of herbaceous species and loss of soil (Diamond and True 2008). Our study showed that large-scale woody vegetation pixel loss patches occurred more frequently on steep slopes than expected relative to a random distribution determined from the grid analysis of the study site. Steep-slope, large-scale woody vegetation pixel loss patches occurred the most on south- and west-facing slopes. Steep south- and westfacing slopes are generally drier and more likely to ignite and carry intense fire (Fule and Covington 1998). Although reducing woody vegetation in this landscape may be optimized by focusing on south- and west-facing steep slopes predisposed to disturbance, increasing herbaceous cover may be better optimized in other areas.

We attribute the change in the number of large-scale woody vegetation pixel loss patches observed over time to historical factors related to land use changes and altered fire occurrence. Major vegetation change coinciding with European settlement of this region began at the end of the 19th century and continued into the early part of the 20th, resulting from activities such as juniper harvesting, land clearing, and alteration of the fire regime (Bray 1904; Foster 1917; Wills 2005). Interactions occur as a result of land use changes or climate variability that alter fire regimes and are associated with gain or loss of woody vegetation (Lezberg et al. 2008; Stephens et al. 2009). We consider changes in the fire regime to be the most important direct driver of woody vegetation change within the study area.

A fire history study of the area indicated that fire was common early in the century and peaked in the 1950s (Murray and White, in press). Charring is apparent on many cut stumps within BCNWR, indicating either intentional burning or accidental fire carried by increased fine fuels following canopy clearing. Ashe's juniper, the dominant woody species for our study site, is a fire-sensitive, nonsprouting evergreen species (Wink and Wright 1973; Diamond 1997) and may require > 20 yr to recapture sites following intense fire (Reemts and Hansen 2008). Some juniper species, such as redberry juniper, can resprout following top kill (Ueckert et al. 2001), allowing quicker and more complete regrowth following disturbance. Differences in sprouting ability further contribute to sitespecific differences in woody vegetation change within the southern Great Plains.

Although site differences potentially exist that influence growth rates, the length and frequency of observations from the historical aerial photographs we used revealed interdecadal variability important for interpreting results. Interpreting loss or gain of woody vegetation from the landscape is associated with a reference point in the past. For example, an observer viewing this landscape in 1980 and 2004 would conclude that woody vegetation is expanding (Fig. 2). For our study, we showed that total area of woody vegetation was potentially similar from 1937 to 2004. This necessitates contextualizing interpretation of woody plant growth as either regrowth or encroachment. The lack of aerial photographs before the 1930s may require assessment with biochemical surrogates, such as stable carbon isotopes, which may retain chemical signatures of past dominant vegetation (Archer 1995).

The average change in pixels classified as woody vegetation of $31.5 \%$ (Fig. 3) was due to both small- and large-scale contiguous woody vegetation patch formation change (Fig. 4).
We interpreted individual tree loss due to self-thinning and weather-related damage primarily from ice storms and windthrow, which occur in this area approximately every $3 \mathrm{yr}$ (Chagnon and Chagnon 2002; Bragg et al. 2003). Ice storms affect juniper trees primarily due to the low modulus of elasticity of its wood tissue that breaks under the weight of ice in the canopy (Soulé and Knapp 2007). Assessment of smallscale disturbance through this type of remote sensing is possible with the small spatial resolution of the photographic data coupled with careful georegistration and radiometric normalization of the digital data through time (Browning et al. 2009).

Although differences among historical aerial photographs were minimized with processing, inconsistencies among sequential aerial photos exist that include differences in film and camera types, flight altitudes, and timing of acquisition that that can affect interpretation of vegetation changes over time (Table 1). The georectification and normalization process presented here should minimize image brightness and spatial resolution differences in the data. Time-of-year differences among the images did exist but were minimized because deciduous trees generally have similar brightness values in the visible spectrum for growing and nongrowing seasons. Shadows also are a potential source of error in processing and interpretation when utilizing threshold methods of classification. However, classification errors associated with shadows may be offset by increased brightness on the opposite side of individual or groups of trees. For our study, assessment of small-scale patches may have been affected by these errors; however, the percentage of area we found, 11.1-12.6\%, showed consistent change in the woody vegetation canopy that is likely to be, in part, driven by fine-scale disturbances. The photographic errors are less likely to have influenced the analysis of large-scale patches, where large-scale $(>1$ ha, or 10000 pixels) changes in woody vegetation were identified. These changes are beyond simple photographic processing artifacts and likely the result of broad disturbances across the BCWNR landscape.

\section{IMPLICATIONS}

We developed a consistent methodology for detecting woody vegetation change that we applied to grasslands of the Edwards Plateau to discern woody vegetation encroachment and disturbance through time. Analysis of sequential historical aerial photographs provided documentation of past variability of woody vegetation cover where in situ data did not exist and indicated that observation frequency is important for the interpretation of woody vegetation encroachment. Analysis of shape and size of areas with contiguous change in woody vegetation cover provided information regarding potential disturbance types when used with ancillary historical data. Our results indicate that, although this area has not increased in overall area of woody vegetation from 1937 to the present, there have been changes in the location and size of woody patches within these grasslands that may have been mistakenly interpreted as encroachment. Our results support the idea that land use-driven changes in woody vegetation across the southern Great Plains are site specific and not always directional and homogeneous. 


\section{ACKNOWLEDGMENTS}

We would like to acknowledge D. Holle, C. Schwope, and C. Sexton of BCNWR for support in the field. We would also like to thank T. Roerhig of TNRIS, A. Gonzales of the University of Texas, and A. Adhikari, M. Sides, J. Thomas, and J. Yao of the Baylor Spatial Ecology Lab.

\section{LITERATURE CITED}

Allen, C. D., and D. D. Breshears. 1998. Drought-induced shift of a forest-woodland ecotone: rapid landscape response to climate variation. Proceedings of the National Academy of Sciences of the United States of America 95:1483914842.

Ansley, R. J., D. N. Ueckert, and W. E. Pinchak. 1995. Changes in redberry juniper distribution in northwest Texas (1948 to 1982). Rangelands 17:49-53.

ARCHER, S. 1995. Tree-grass dynamics in a Prosopis-thornscrub savanna parklandreconstructing the past and predicting the future. Ecoscience 2:83-99.

Archer, S., C. Scifres, C. R. Bassham, and R. Maggio. 1988. Autogenic succession in a sub-tropical savanna: conversion of grassland to thorn woodland. Ecological Monographs 58:111-127.

Banfal, D. S., and D. M. J. S. Bowman. 2006. Forty years of lowland monsoon rainforest expansion in Kakadu National Park, Northern Australia. Biological Conservation 131:553-565.

Bormann, F. H., AND G. E. LIKENS. 1979. Pattern and process in a forested ecosystem. New York, NY, USA: Springer-Verlag. 253 p.

Bowman, D. M. J. S., A. Walsh, And D. J. MILnE. 2001. Forest expansion and grassland contraction within a eucalyptus savanna matrix between 1941 and 1994 at Litchfield National Park in the Australian monsoon tropics. Global Ecology \& Biogeography 10:535-548.

BragG, D. C., B. Zeide, and M. G. Shelton. 2003. Impacts and management implications of ice storms on forests in the southern United States. Forest Ecology and Management 186:99-123.

Bray, W. L. 1904. The timber of the Edwards Plateau of Texas: its relations to climate, water supply, and soil. Washington, DC, USA: USDA Bureau of Forestry. Bulletin no. 49.30 p.

BrigGs, J. M., G. A. Hoch, AND L.C. JoHnson. 2002. Assessing the rate, mechanisms, and consequences of the conversion of tallgrass prairie to Juniperus virginiana forest. Ecosystems 5:578-586.

Browning, D. M., S. R. Archer, G.P. Asner, M. P. McClaran, and C. A. Wessman. 2008. Woody plants in grasslands: post-encroachment dynamics. Ecological Applications 18:928-944.

Browning, D. M., S. R. Archer, And A. T. Byrne. 2009. Field validation of 1930's aerial photography: what are we missing? Journal of Arid Environments 73:844-853.

Chagnon, S. A., And J. M. Chagnon. 2002. Major ice storms in the United States, 19492000. Environmental Hazards 4:105-111.

Coppedge, B. R., D. M. Engle, S. D. Fuhlendorf, R. E. Masters, and M. S. Gregory. 2002. Landscape cover type and pattern dynamics in fragmented southern Great Plains grasslands, USA. Landscape Ecology 16:677-690.

Diamond, D. D. 1997. An old-growth definition for western juniper woodlands: Texas Ashe juniper dominated or codominated communities. General Technical Report SRS; 15. Asheville, NC, USA: USDA Forest Service Southern Research Station. General Technical Report SRS 15. $15 \mathrm{p}$.

Diamond, D. D., And C. D. True. 2008. Distribution of Juniperus woodlands in Central Texas in relation to general abiotic site type. In: 0 . W. Van Auken [ED.]. Western North American Juniperus communities: a dynamic vegetation type. Ecological Studies, vol. 196. New York, NY, USA: Springer. p. 48-56.

Drummond, M. A., R. F. Auch, K. A. Karstensen, K. L. Sayler, J. L. Taylor, and T. R. Loveland. 2012. Land change variability and human-environment dynamics in the United States Great Plains. Land Use Policy 29:710-723.

Engle, D. M., B. R. Coppedge, and S. D. Fuhlendorf. 2008. From the dust bowl to the green glacier: human activity and environmental change in Great Plains grasslands, In: 0. W. Van Auken [ED.]. Western North American Juniperus communities: a dynamic vegetation type. Ecological Studies, vol. 196. New York, NY, USA: Springer. p. 253-271.
Fensham, R. J., S. J. Low Choy, R. J. Fairfax, and P. C. Cavallaro. 2003. Modelling trends in woody vegetation structure in semi-arid Australia as determined from aerial photography. Journal of Environmental Management 68:421-436.

Foster, J. H. 1917. The spread of timbered areas in Central Texas. Journal of Forestry. 15:442-445.

FuHLendoRF, S. D., AND F. E. Smeins. 1997. Long-term vegetation dynamics mediated by herbivores, weather and fire in a Juniperus-Quercus savanna. Journal of Vegetation Science 8:819-828.

Fule, P. Z., AND W. W. Covington. 1998. Spatial patterns of Mexican pine-oak forests under different recent fire regimes. Plant Ecology 134:197-209.

Kettle, W. D., P. M. Rich, K. Kindscher, G. L. Pittman, and P. Fu. 2000. Land-use history in ecosystem restoration: a 40-year study in the prairie-forest ecotone. Restoration Ecology 8:307-317.

Lawes, M. J., D. M. Macfarlane, and H. A. C. Eeley. 2004. Forest landscape pattern in the KwaZulu-Natal midlands, South Africa: 50 years of change or stasis? Austral Ecology 29:613-623.

Lezberg, A. L., M. A. Battaglia, W. D. Shepperd, and A. W. Schoettle. 2008. Decadesold silvicultural treatments influence surface wildfire severity and post-fire nitrogen availability in a ponderosa pine forest. Forest Ecology and Management 255:49-61.

McGarigal, K. S., A. Cushman, M. C. Neel and E. E. Ene. 2002. fRAGStatS: spatial pattern analysis program for categorical maps. Amherst, MA, USA: University of Massachusetts, Amherst. Available at: http://www.umass.edu/landeco/research/ fragstats/fragstats.html. Accessed 17 October 2009.

MilleR, R. F., AND J. A. Rose. 1999. Fire history and western juniper encroachment in sagebrush steppe. Journal of Range Management 52:550-559.

Mueller, R. C., C. M. Scudder, M. E. Porter, R. T. Trotter III, C. A. Gehring, and T. G. WhiтнAм. 2005. Differential tree mortality in response to severe drought: evidence for long-term vegetation shifts. Journal of Ecology 93:1085-1093.

Narumalani, S., D. R. Mishra, and R. G. Rothwell. 2004. Change detection and landscape metrics for inferring anthropogenic processes in the greater EFMO area. Remote Sensing of Environment 91:478-489.

National Oceanic and Atmospheric Administration. 2009. Comparative climatic data. Available at: http://www.noaa.gov/climate.html. Accessed 20 August 2009.

Reemts, C. M., And L. L. Hansen. 2008. Slow recolonization of burned oak-juniper woodlands by Ashe juniper (Juniperus ashei): ten years of succession after crown fire. Forest Ecology and Management 255:1057-1066.

Rippel, P., G. A. Lymbery, And R. D. Pieper. 1983. Vegetational evaluation of pinyon-juniper cabling in south-central New Mexico. Journal of Range Management 36:13-15.

Sankaran, M., N. Hanan, R. Scholes, J. Ratnam, D. Augustine, B. Cade, J. Gignoux, S. Higgens, X. Le Roux, F. Ludwig, J. Ardo, F. Banyikwa, A. Bronn, G. Bucini, K. Caylor, M. Coughenour, A. Diouf, W. Ekaya, C. Feral, E. February, P. Frost, P. Hiernaux, H. Hrabar, K. Metzger, H. Prins, S. Ringrose, W. Sea, J. Tews, J. Worden, and N. ZamBATIS. 2005. Determinants of woody cover in African savannas. Nature 438:846-849.

Scholes, R. J., And S. R. ArCher. 1997. Tree-grass interactions in savannas. Annual Review of Ecology and Systematics 28:517-544.

Sellards, E. H., F. B. Plummer, and W. S. Adkins. 1933. The geology of Texas. Austin, TX, USA: University of Texas. Bulletin no. 3232. $1007 \mathrm{p}$.

SoulÉ, P. T., AND P. A. KnAPP. 2007. Topoedaphic and morphological complexity of foliar damage and mortality within western juniper (Juniperus occidentalis var. occidentalis) woodlands following an extreme meteorological event. Journal of Biogeography 34:1927-1937.

Stephens, S. L., J. J. Moghaddas, C. Edminster, C. E. Fiedler, S. Haase, M. Harrington, J. E. Keeley, E. E. Knapp, J. D. Mclver, K. Metlen, C. N. Skinner, and A. Youngblood. 2009. Fire treatment effects on vegetation structure, fuels, and potential fire severity in western U.S. forests. Ecological Applications 19:305-320.

Swetnam, T. W., C. D. Allen, and J. L. Betancourt. 1999. Applied historical ecology: using the past to manage for the future. Ecological Applications 9:1189-1206.

Swetnam, T. W., AND J. L. Betancourt. 1998. Mesoscale disturbance and ecological response to decadal climatic variability in the American Southwest. Journal of Climate 11:3128-3147.

Ueckert, D. N., R. A. Phillips, J. L. Petersen, X. Ben Wu, and D. F. Waldren. 2001. Redberry juniper canopy cover dynamics on western Texas rangelands. Journal of Range Management. 54:603-610. 
US Fish and Wildife Service. 1992. Golden-cheeked warbler (Dendroica chrysoparia) recovery plan. Albuquerque, NM, USA: US Fish and Wildlife Service. $88 \mathrm{p}$.

US Geological SuRvey. 2006. Digital representations of tree species range maps from "Atlas of United States trees" by Elbert L. Little, Jr. (and other publications). Available at: http://esp.cr.usgs.gov/data/atlas/little. Accessed 20 July 2009.

Van Auken, 0. W. 2000. Shrub invasions of North American semiarid grasslands. Annual Review of Ecology and Systematics 31:197-215.

Van Auken, 0. W. 2008. Western North American Juniperus communities: a dynamic vegetation type. Ecological Studies, vol. 196. New York, NY, USA: Springer. $336 \mathrm{p}$.
Van Auken, 0. W., J. T. Jackson, and P. N. Jurena, 2004. Survival and growth of Juniperus seedlings in Juniperus woodlands. Plant Ecology 175: 245-257.

WiLLS, F. H. 2005. Structure of historic vegetation on Kerr Wildlife Management Area, Kerr County, Texas. Texas Journal of Science 57:137-152.

Wink, R. L., AND H. A. Wright. 1973. Effects of fire on an Ashe juniper community. Journal of Range Management 26:326-329.

Woodward, F. I. 1987. Climate and plant distribution. Cambridge, UK: Cambridge University Press. $188 \mathrm{p}$.

YaO, J., D. B. Murray, A. AdhiKarl, and J. D. White. 2012. Fire in a sub-humid woodland: the balance between carbon sequestration and habitat conservation. Forest Ecology and Management 280:40-51. 